\title{
Over Fossil Fueled: The Fundamentals for a Low-Carbon Diet
}

\author{
Mark Callis Sanders*1, Charlotta E Sanders ${ }^{2}$ and Marshall H. Tuten ${ }^{3}$ \\ ${ }^{1}$ Sanders Engineering, USA \\ ${ }^{2}$ Department of Mechanical Engineering, University of Nevada, Las Vegas, USA \\ ${ }^{3}$ Slippery Rock University, USA
}

Submission: October 26, 2018; Published: December 13, 2018

*Corresponding author: Mark Callis Sanders, Sanders Engineering, Las Vegas, USA

\begin{abstract}
The Intergovernmental Panel on Climate Change (IPCC) issued a challenge to the international community to achieve even greater reductions in carbon emissions than was previously believed desirable with its report on October 08,2018 . This will require a fundamental reevaluation of our current perspectives regarding a comprehensive energy strategy, given that economic growth is closely allied with energy use. World energy demand is likely to continue to increase, especially among those countries with an expanding population and/or expectations for higher standards of living. Thus, the task for policy-makers is to create an environment allowing power-generating methods to flourish, thereby establishing a stable, efficient, cost effective foundation of all available low-carbon sources of power production in supporting an expanding national economy. This commentary highlights a few of the challenges, benefits, and risks of the global transition from a fossil fuel based economy to green energy alternatives.
\end{abstract}

Keywords: Climate Change; Energy Policy; Globalization; Green Technology; Fossil Fuels; Economy

Abbrevations: IPCC: Intergovernmental Panel on Climate Change, EROI: Energy Return on Investment

\section{Introduction}

With the release of the Intergovernmental Panel on Climate Change (IPCC) report "Global Warming of $1.5^{\circ} \mathrm{C}$, an IPCC special report on the impacts of global warming of $1.5^{\circ} \mathrm{C}$ above preindustrial levels and related global greenhouse gas emission pathways, in the context of strengthening the global response to the threat of climate change, sustainable development, and efforts to eradicate poverty" [1] on October 8, 2018, once again the Global debate surrounding the stark realities of earth's warming climate is staring us in the face. In its report, the IPCC recommended limiting global warming by $1.5^{\circ} \mathrm{C}$ above pre-industrials levels, thereby reducing the greater impacts to human life and the global ecosystem than those consequences currently believed associated with a $2.0^{\circ} \mathrm{C}$ increase. This report reignites the global policy-making chess game, as each State and advocacy group begins to lobby for its own self-interest, while checkmating the counter parties to gain the economic advantage.

\section{Carbon dieting struggles}

Much commentary will be put forward from all sides during the implementation part of this policy-making chess game. However, one important and unalterable take away from the IPCC report is that there must be a concerted effort by the international community in bringing about a significant global reduction in carbon emissions. The overarching feature in this dilemma is that now, more than ever before since humankind's successful control of using fire for industrial applications, economic output and growth potential is systemically interrelated with energy use. As earth's population continues to expand, with the coupled forward progression of developing and under-developed economies, world energy demand is only likely to continue to increase exponentially. Therefore, the imposing task for more developed States is to reduce global carbon emission output to combat the warming climate, without causing substantial self-economic harm. It may also require that these more fully developed and economically superior economies assist, financially or otherwise, lessdeveloped/under developed States to cultivate and transition to low/zero carbon energy sources. Such a resultant transfer of wealth of this so called "green" money from 'rich' to 'poor' States may not currently, and for a foreseeable future, be feasible given the realities of a number of States' track toward more nationalistic overtones. 
Globalization and the interconnectivity to the national economy through a disruption in global energy markets was first made plain for Western industrialized nation states during the oil crises of the 1970's. Since then, energy markets have only become more intertwined. Globalization and its impact on global commodity prices since the mid-2000's for fossil fuels and green technology alternatives show a direct causal effect on local policy perspectives with some States rapidly transitioning away from fossil fuels to low carbon sources of energy production. These technologically advanced and more financially stable economies are better situated to absorb any impacts to the national economy associated with such changes, but this is having a discriminatory impact on developing and under-developed economies in their struggle to gain access to these emergent technologies, given their limited resources and infrastructure.

The rapid rise in economic output experienced by developing States over the last several decades, especially in Asia, is strongly associated with the use of fossil fuels. Currently, fossil fuels are integral to power-generating capacity, promoting positive capital streams for these developing nation states. This positive flow of capital manifests itself in the form of infrastructure maturity, transportation route expansion, and new industries fermenting job creation allowing for continued growth, innovation, and development, with a significant increase in the standard of living for an expanding middle class. Studies in Bangladesh, for example, demonstrate that government investment in rural electrification, 96\% of which comes from fossil fuels today, dramatically reduces what is known as 'energy poverty' among the rural poor [2]. Thus, implementing low/zero carbon energy solutions has the potential to initiate an extreme burden upon these States, where fossil fuel use is currently driving poverty alleviation through these pathways for sustained upward economic development.

\section{Short and long term areas of study}

In the short term, one area of suggested research is to seek a better understanding of the complexities of the Energy Return on Investment (EROI) for nuclear power and other green technologies, given that all power-generating systems emit carbon emissions in either the front-end, operational, or the back-end cycles of use. This is not an easy task given the range of literature and different methods for deriving the final output of each power-generating source, with varied modeling differences, which are exacerbated by the variance in processes among these various power-generating systems. This may also require a realignment in attitudes to comport policy goals regarding which power-generating system provides the overall ability to positively limit or reverse the negative impact on global climate change, while maintaining the sought after efficiency, stability and growth potential of the national economy.

Other areas of recommended research and policy-making is how we can better harmonize the best use of all available low/zero carbon emission power-generating systems to maximize efficiency and stability. As other future low/zero carbon power-generating systems are developed, we should begin now to comprehend and recognize the historical patterns of these past developed low carbon emission technologies to comprehend what worked/what failed in their roll out phases, to contemplate a successful template for bringing forward these future developed low/zero carbon technologies. Finally, the formation of pragmatic attitudes is needed that in discussing global climate change, no nation is an island unto itself. The elephant in the room is how much are certain economically advantaged States willing to sacrifice some level of their standard of living for the greater good of the global community?

\section{Conclusion}

The task of transitioning from a fossil fuel based economy to green technology alternatives will require a combined local, regional, and international response. The consequences of climate change will affect each nation state, and the citizens of those States, in different and unique ways, but it will affect them. Thus, each State and citizen are stakeholders in determining how best to meet this global test. There are no easy answers in this policy-making chess game, but there is a straightforward goal - The global community must come together to dramatically reduce worldwide carbon emissions.

\section{References}

1. "Global Warming of $1.5^{\circ} \mathrm{C}$, an IPCC special report on the impacts of global warming of $1.5^{\circ} \mathrm{C}$ above pre-industrial levels and related global greenhouse gas emission pathways, in the context of strengthening the global response to the threat of climate change, sustainable development, and efforts to eradicate poverty", International Governmental Panel on Climate Change.

2. Barnes DF, Khandker S and Samad H (2011) Energy Poverty in Rural Bangladesh. Energy Policy 39(2): 894-904. 


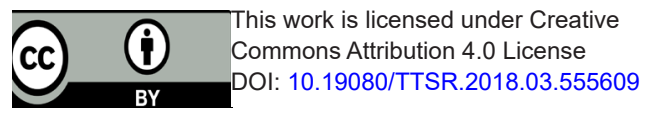

\section{Your next submission with Juniper Publishers will reach you the below assets}

- Quality Editorial service

- Swift Peer Review

- Reprints availability

- E-prints Service

- Manuscript Podcast for convenient understanding

- Global attainment for your research

- Manuscript accessibility in different formats

( Pdf, E-pub, Full Text, Audio)

- Unceasing customer service

Track the below URL for one-step submission https://juniperpublishers.com/online-submission.php 
